DOE/TIC-11303

$\frac{235}{12.5 \cdot 90}$

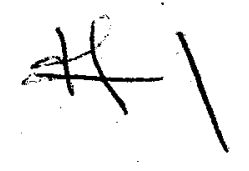

Dr. 2090

\title{
Comparative Assessment of Five Potential Sites for Hydrothermal-Magma Systems:
} Summary

November 1980

\section{U.S. Department of Energy}

Office of Energy Research

Division of Engineering, Mathematical and Geosciences

Under Contract NO. DE-AC04-76DP00789

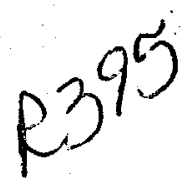




\section{DISCLAIMER}

This report was prepared as an account of work sponsored by an agency of the United States Government. Neither the United States Government nor any agency Thereof, nor any of their employees, makes any warranty, express or implied, or assumes any legal liability or responsibility for the accuracy, completeness, or usefulness of any information, apparatus, product, or process disclosed, or represents that its use would not infringe privately owned rights. Reference herein to any specific commercial product, process, or service by trade name, trademark, manufacturer, or otherwise does not necessarily constitute or imply its endorsement, recommendation, or favoring by the United States Government or any agency thereof. The views and opinions of authors expressed herein do not necessarily state or reflect those of the United States Government or any agency thereof. 


\section{DISCLAIMER}

Portions of this document may be illegible in electronic image products. Images are produced from the best available original document. 


\section{Comparative Assessment of Five Potential Sites for Hydrothermal-Magma Systems: .} Summary

November 1980

Prepared by:

W. C. Luth and H. C. Hardee Sandia National Laboratories Albuquerque, New Mexico 87185

\section{U.S. Department of Energy}

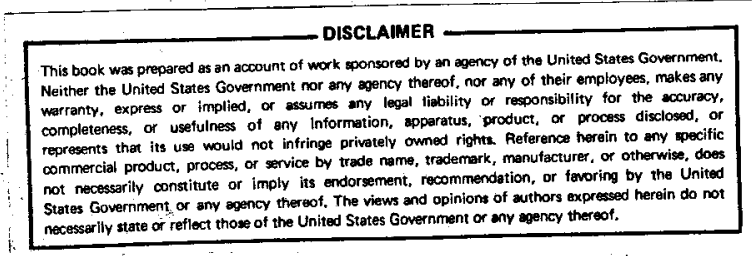

Office of Energy Reseärch

Division of Engineering, Mathematical and Geosciences

Washington, D.C. 20585

Under Contract NO. DE-AC04-76DP00789 
with contributions from

F. Goff, Los Alamos National Sclentific Laboratory

P. Kasameyer, Lawrence Livermore National Laboratory

A. White, Lawrence Berkeley Laboratory

J. Eichelberger, Sandia National Laboratories

SAND $80-2582$ 


\section{ABSTRACT}

An objective of the Thermal Regimes portion of the Continental Scientific Drilling Program (CSDP) is the development of a fundamental understanding of energy transport within and between hydrothermal and magma systems. A comparative assessment of five potential hydrothermal-magma sites for this facet of the Thermal Regimes part of the CSDP has been prepared for the DOE Office of Basic Energy Sciences. Four DOE Laboratories (Los Alamos National Scientific Laboratory, Lawrence Berkeley Laboratory, Lawrence Livermore National Laboratory, and Sandia National Laboratories) participated in this study. The five sites are: The Geysers-Clear Lake, CA, Long valley, CA, Rio Grande Rift, NM, Roosevelt Hot Springs, UT, and Salton Trough, CA. This site assessment study has drawn together background information (geology, geochemistry, geophysics, and energy transport) on the five sites as a preliminary stage to site selection. criteria for site. selection are that potential sites have identifiable, or likely, hydrothermal systems and associated magma sources, and that important scientific questions can be identified and answered by deep scientific holes.

It is recommended that adequate drilling, logging, and instrumentation technology be developed to permit resolution of the scientlfic questlons. It is also recommended that further activities center about the Valles Caldera, The Geysers-clear Lake Region, and the Salton Trough with the valles caldera offering the greatest advantage. 
FOREWORD

The future supplies of energy and related mineral resources in the Onited states require an Increasing level of knowledge bearing on the deeper portions of the earth's continental crust. Magma-hydrothermal systems are significant energy resources. They also produce geochemical concentrations of essential mineral resources, includIng urantum, thortum and other important metals. The migration of elements in the presence of a heat source and groundwater also has obvious application for the study of nuclear waste isolation.

The National Academy of Sclences workshops on continental drilling in 1974 and 1978 recognized the importance of the thermal reglme in energy and mass transport systems. The Department of Energy, through four of its laboratories, has assumed an early role in the Continental Scientif 1c Drilling Project by sponsoring the comparatIve assessment of five potential sites for studies of magma-hydrothermal systems through deep drilling. structural, stratigraphic and petrological information obtalned from rock and fluid samples obtalned by drililing are needed to callbrate and supplement existing geophysical and geochemlcal methods and technlques. Temperature, permeability, porosity and other lmportant variables can only be measured in a meaningful way under In situ conditions. Thus, carefully selected drilling targets will help to define the third dimension of the earth as no other method can. The Department of Energy will assist the geosclence comminity in meeting the challenges and surprises that awalt such an undertaking. 


\section{POTENTIAL SITES FOR HYDROTHERMAL-MAGMA SYSTEMS}

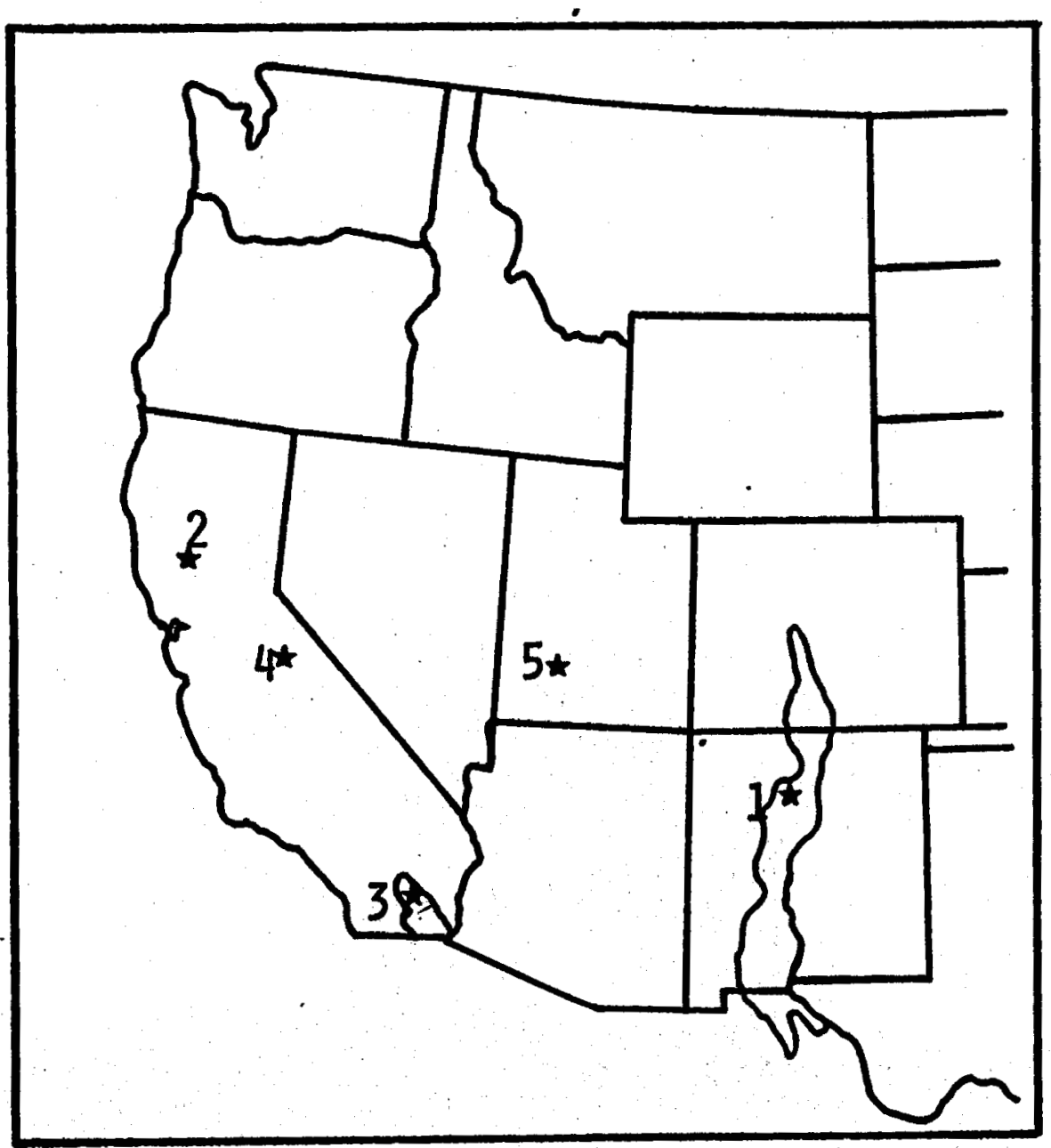

1. Rio Grande Rift (Valles Caldera), New Mexico

2. The Geysers-Clear lake, California

3. Salton trough, California

4. Long Valley, California

5. ROOSEVELT HOT SPRINGS, UTAH 
OUTLINF

1. INTRODUCTION

4

2. TRANSPORT SUMMARY

7

3. GEOLOGY SUMMARY 12

4. GFOCHEMISTRY SUMMARY 20

5. GEOPHYSICS SUMMARY 24

6. RFSEARCH AND DRILLING AT SPFCIFIC SITFS 33

Salton Prough

Rio Grande Rift $\quad 38$

Iong Valley $\quad 42$

The Geysers - Clear Lake 44

Roosevelt hot Springs 48

7. CONCLUSIONS $; \quad 48$ 


\section{INTRODUCTION}

\section{Background}

Following the Workshop on Continental Drilling for Scientific Purposes held at Los Alamos, New Mexico, July 17-21, 1978, a National Academy of Sciences report was issued entitled "Continental Scientific Drilling Program." The report Identified primary scientific objectives in four major areas: Basement Structures and Deep Continental Basins; Thermal Regimes; Mineral Resources: and Earthquakes. The Department of Energy has a particular interest in thermal regimes because of the Department's need to understand thermally driven processes related to utilization of energy resources and the disposition of heat producing wastes in the geologic environment. Although utilization of geothermal energy, and disposition of geothermal fluids, are the most obvious examples of thermal effects in geologic media, there are parallels in the areas of in situ fossil fuel utilization and nuclear waste disposal.

Under the topical heading of thermal regimes, the workshop report identified five specific regimes: Vapor-dominated hydrothermal convection systems (The Geysers); hot-water hydrothermal systems driven by high-level igneous intrusions (Yellowstone, Salton Sea, Valles Caldera); hot-water geothermal systems driven by regional conductive heat flow (Nevada, Utah); thermal and chemical processes in active volcanic regions (Hawail, Cascades, Alaska); and thermal processes in stable regions. Several of these regimes involve a linkage between magmatic and 
hydrothermal systems. Thus one broad objective of the thermal regimes portion of the Continental scientific Drilling Program might be phrased as follows:

The development of an understanding of energy and mass transport within, and between magmatic and hydrothermal systems through a scientifically directed program of shallow, moderate and deep drililing, sampling, and experimentation in the continental crust.

A joint proposal to conduct a comparative assessment of five potential hyarothermal-magma sites was prepared and submitted to the Department of Energy's Office of Basic Energy Sciences, Geoscience Program in November of 1979. The four DOE laboratories involved were: Ios Alamos National scientific Laboratory, Lawrence Berkeley Iaboratory, Lawrence Livermore National Laboratory, and Sandia National Laboratories. The five sites selected were: The Geysers, California, Iong Valley, California, the Salton Trough, California, Roosevelt Hot Springs, Utah, and the Rlo Grande Rift, New Mexico.

Five sites were selected, rather than a greater number, because of the desire to prepare a report during the 1980 fiscal year. These five sites were selected on the basis of recommendatIons of three workshops (Ghost Ranch workshop on Continental Drilling, June 10-13, 1974, DOE Workshop on Magma/Hydrothermal Drilling and Instrumentation, May 31 -June 2, 1978 , and the NAS Workshop on a Continental scientifle Drilling Program, July 17-21, 1978) involving widespread participation from the scientific community. Because of strong recommendations in the NAs workshop 
Report on use of technological drill holes for "add-on" scientific purposes, the five sites selected for this study are themselves the subject of intensive geothermal exploration, by arilling. These five sites are believed to involve the broddest and most intensive existing data base of any of the potential continental sites other than Yellowstone. It should not be construed that specific consideration of these five sites represents an elimination of any other site or sites. There is a need for similar assessments of other potential sites, for example, the volcanic sequences of the Cascades. Time constraints prevented the inclusion of additional sites in this report. objective of the comparative site Assessment

The objective of this comparative-site assessment is to review the available information pertinent to each site and to identify specific scientific questions which may be resolved through drilling, sampling, and down-hole experiments at each site. Sites may then be ranked in terms of the significance of the questions, additional surface data requirements, testability of site specific transport models, and sequence or timing of proposed arilling efforts. In addition, the comparative site assessment provides a basis for utilizing existing (or planned) holes to investigate scientific questions. A comparative site assessment is a necessary preliminary step in the broader site selection process. 
Comparative Site Assessment Procedure

Earth scientists from each of the four DOE laboratories participated in the preparation of the geology, geochemistry, geophysics, and energy transport review papers. Sandia was assigned the responsibility of coordinating the effort. The overall Comparative site Assessment consists of five separate, but related, documents, Each laboratory has published, through its internal publication system, a review document where the author is the chairman of the discipline-oriented review group:

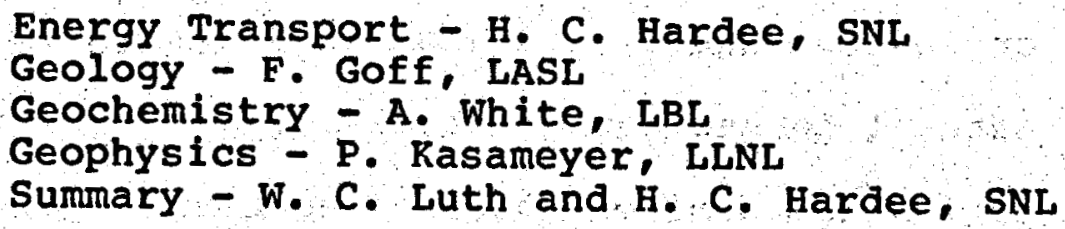

The summary report is drawn from the four review papers. Generic drilling opportunities are identified and specific research and drilling plans are proposed at each of the five sites.

\section{ENERGY TRANSPORT SUMMARY}

\section{Energy Transport Regimes}

The subject of heat and mass transport within and between the hydrothermal and magma system encompasses a wide range of possible thermal processes including: conduction, radiation, enclosed natural convection, and single and multiphase permeable convection. There are three principal thermal zones: the magma zone, the hydrothermal zone, and the intermediate or transition 
zone between the two. An aditional localized zone of critical state convection may exist in special situations.

Thermal sites of the type considered in this study obviously have, or had, magma as the basic source of heat. In some cases, the magma may exist as a large single hody and in other cases it may exist as a plexus of dikes and sills. The magma body may be continuously or episodically resupplied or it may have been emplaced in a single intrusive event. Depending on the type of magma (basaltic, andesitic, rhyolitic), viscosity and proportions of crystals, liquid, and gas, the magma body may have internal natural convection or it may be virtually stagnant with conduction the dominant mode of heat transfer. In some areas the magmatic source of heat may be uncertain and the magma body may be laterally displaced from the surface thermal anomaly or hydrothermal zone. The hydrothermal zone in this case can be produced by a lateral and gradual upward movement of heated groundwater from the vicinity of the magma body. Efficient thermal and mass transport in many hydrothermal zones tends to mask thermal information from the deeper magma body. The nature and position of the suspected magma body are important in assessing the thermal processes expected at particular sites. Thermal processes in the transition zone between the hydrothermal zone and the magma body are largely unknown. The transition zone may be a region of porous convective brine circulation which extends down to and perhaps even into the 
magma. Another possibility is that the transition zone is one where conductive heat transfer is dominant because the rock Is impermeable to fluid or because heat transport is reduced when the temperature exceeds the critical temperature of the hydrothermal fluid.

An aditional thermal zone which might exist in special. situations is a zone of critical state natural convection. This can occur at significant depths in the crust $(2-10 \mathrm{~km})$ where the local pore pressure and temperature reach the critical pressure and temperature of water. The depth where this can occur depends on the local in situ pore pressure and the salinity of the pore water. At the critical point, natural convective heat transfer Increases dramatically. This zone could have a significant Impact on the overall heat transfer in the magma/hydrothermal system and would possibly show extensive effects of dissolution and precipitation caused by the enhanced convective circulation. Critlcal convection zones have been suggested as a mechanism for ore deposition and these zones may also provide a preferred site for $s 111$ emplacement of magma.

Research Needs

Most energy transport questions relate to the in situ convective and conductive mechanisms active in the Magma-TransitionHydrothermal zones. While there is no shortage of models of geothermal and magma systems, there is a scarcity of data which are required to evaluate energy transport. Such data are needed 
to discriminate between and improve on models that are presently based on indirect information (e.g., exhumed or fossilized systems). The following typical questions are among many of interest :

What factors distinguish one zone from the other? For example, is permeability a controlling factor in distinguishing the various zones?. What is the effect of fractures, dissolution (secondary porosity) and precipitation (sealing) on permeability? If convection dominates, what fluid phases exist?

What is the maximum depth of fluid circulation? For instance, what is the maximum depth to which downward percolating meteoric waters circulate? Do brines circulate downward to the magma surface or even into the magma?

What are the necessary conditions for the formation of vapor-dominant and liquid-dominant hydrothermal zones? What are the temperature-pressure-phase-chemicalcharacteristics of these zones? How do these zones evolve with time?

Does critical state permeable convection exist? How would supercritical permeable convection be evident in the field? Is critical state permeable convection a limiting mechanism for temperatures and depths in hydrothermal circulation zones?

What is the nature of magma bodies? What conditions determine whether magma exists primarily as a localized (large liquid body) or diffuse (plexus of dikes and sills) heat source? How is magma emplaced? Is the magma chamber isolated or resupplied? What is the state of convection in the magma chamber?

Efforts to answer these questions will require the collection and interpretation of data from shallow, intermediate. and deep drill holes. The field data will have to be synthesized and interpreted through the use of various analytical or numerical models. 
The most important set of transport data collected from a deep drill hole is

Temperature as a function of depth

Pore-fluid pressure as a function of depth

Fluid phase and composition as a function of depth

Solid and melt (glass) phase proportions, distribution and composition as a function of depth

Nature and magnitude of in situ porosity and in situ permeability with depth

Surface and downhole heat flux measurements

Thermal conductivity and thermal diffusivity at depth

Core and cuttings analyses

Geophysical and geochemical measurements are al so needed to interpret thermal and mass transfer processes. For instance, downhole thermal geophysical measurements and geochemical fluid measurements can yield information about the thermal character of a deeper magma body before it is reached by the arill hole. The synthesis of data will be achieved through the use of mathematical models. Interpretation can be achieved through the use of analytical and numerical solutions. A variety of analytical solutions have appeared in the literature on heat and mass transport problems related to hydrothermal and magma systems. In addition, over the past decade many numerical models have been proposed to handle heat and mass transfer in complex, three dimensional, heterogeneous systems. Considering the quality and quantity of data likely from deep arill holes, 
it appears that current computational abilities far exceed the sophistication warranted by field data.

\section{GEOLOGY}

\section{Comparison of the Five sites}

Surface manifestations of both magmatic and hydrothermal activity are present at all five sites. However, these sites do not fully represent all geologic settings in which magma-hydrothermal systems occur, because they are limited to areas of current geothermal exploration. Nevertheless, they illustrate some of the similar and contrasting geologic conditions under which magma bodies and hydrothermal reservoirs develop.

Important geologic features of these sites are summarized in Table 1. One of the obvious similarities is that present hydrothermal activity is associated with silicic volcanism younger than $1 \mathrm{~m} \cdot \mathrm{y}$. at all five locations, although the volume of silicic lavas, lithologic assemblage, and relationship of volcanic events in space and time differ greatly. The Valles and Long Valley Caldera systems provide strong geologic evidence for the past existence of a single large magma body at shallow depth. Geologic data from the Clear Lake field, and to a lesser extent the Roosevelt field, permit the existence of such a body. There is no geologic evidence for large, single magma bodies at the Salton Trough. 
TABLE 1. Comparative information on volcanic styles, tectonic settings, and hydrothermal reservoirs of five magma-hydrothermal systems.

Volcanic style

silicic volcanic field, mostly dacite with subordinate rhyolite and basalt: few pyroclastic units; age: $2-.01 \mathrm{~m} \cdot \mathrm{y}$.

Long Valley Caldera, CA

Roosevelt Hot Spgs., UT

Salton Trough, CA

Valles Caldera, NM
Silicic caldera with copious rhyolitic ashflow tuffs and rhyolite to dacite domes; age: $.7-<0.1 \mathrm{~m} . \mathrm{y}$.

Bimodal basalt-rhyolite suite; some small ashflow tuffs; age: $.8-<.01 \mathrm{~m} . \mathrm{y}$.

Four rhyolite domes and one dacite dome; age: $<.1 \mathrm{~m} \cdot \mathrm{y}$.

silicic caldera with copious ash-flow tuffs and rhyolite domes; age: $1.4-0.1 \mathrm{~m} . \mathrm{y}$.
Tectonic Setting

Hydrothermal Systems

Adjacent (east) San

Andreas transform zone; located in early Tertiary subduction zone.

Astride Sierra Nevada and Basin and Range Boundary.

East margin of Basin and Range province; adjacent to NW Colorado Plateau.

Overlies transform zone associated with East Pacific Rise and San Andreas fault system.

Junction of Rio Grande rift and Jemez volcanic lineament at SE margin of Colorado Plateau.
Large vapor-dominated reservoir at The Geysers, $\mathrm{T}=240^{\circ} \mathrm{C}$; several distinct hot water reservoirs to east, $T \leq 200^{\circ} \mathrm{C}$; many fumarole areas and mercury deposits.

Several small hot water reservoirs; one fumarole area.

Moderate-sized hot water reservoir, $\mathbf{T}=260^{\circ} \mathrm{C}$.

Many hot water reservoirs, $\mathrm{T} \leq 350^{\circ} \mathrm{C}$; one fumarole area.

Moderate-sized hot water reservoir. $T=260^{\circ} \mathrm{C} ;$ contains small vapor-dominated zone; two fumarole areas. 
There is also a close association between volcanism and tectonic activity at all five sites. The largest magma systems, represented by the Long Valley and Valles Calderas, are centered on normal fault structures with displacements of several kilometers. These magma bodies, and most of the other magmatic systems as well, have apparently developed within and migrated upward along major fault zones. The regional tectonic environ-' ment of volcanism at all sites except clear Lake is extensional, and at The Geysers-clear Lake site a local extensional environment presumably exists. Although the Salton Trough is cut by strike slip faults of the San Andreas system, volcanoes are centered on fault offsets which appear to act as spreading centers. As a consequence of the tectonic activity, all the sites are structurally complex.

Another relationship exists between tectonic and hydrothermal activity. Active tectonism apparently maintains permeability within the hydrothermal reservoirs and provides pathways for the surface manifestation of the tectonism.

All the sites contain zones of water-dominated hydrothermal activity, and vapor-dominated zones also occur at the Geysers-Clear Lake and the Valles Caldera. At Long Valley and Valles Calderas, hydrothermal activity occurs within the caldera structures and has therefore developed primarily in silicic pyroclastic rocks. Reservoir rocks are sedimentary or metamorphosed sedimentary materials at the Salton Trough 
and The Geysers and mylonitized granitic basement at Roosevelt Hot springs.

Although magmatic and hydrothermal activity are clearly associated at all sites, the character of this relationship varies greatly. Evidence at Long Valley and the Valles Caldera suggests that the hottest part of the hydrothermal systems are centered over the shallowest portion of the magmatic system. However, at The Geysers and Roosevelt Hot Springs, hydrothermal activity is displaced laterally from the associated volcanic fields, and at the Salton Trough, surface expressions of volcanism are minor in areal extent relative to the hydrothermal activity. Table 2 shows that there is no apparent relationship between energy contained in each hydrothermal system and the volume of associated volcanic rocks.

Three of the five sites belong to two widespread classes of systems: rifts and calderas. Results of drilling at these sites have the potential for wider application than at the more unique systems. Continental rifts, of which the Rio Grande Rift and Salton Trough are examples, are characterized by an elongate zone of extensional tectonics, basaltic volcanism or intrusions, high heat flow, high electrical conductivity in the crust or mantle, thin crust, and positive gravity residuals (when the effect of low density basin fill is subtracted). These features are generally interpreted as a consequence of mantle upwelling and crustal spreading. The anomalous thermal 
MABLE 2. Total estimated thermal energy of five magmahydrothermal systems (to a depth of $10 \mathrm{~km}$ ) compared with thermal energy of associated hydrothermal systems and volumes of associated silicic volcanics: data from USGS circs. 726 and 790 (1975, 1978).

Thermal energy in magma-hydrothermats system,
Thermal energy in associated hydrothermal
Volume of associated silicic volcanics, mostly

$1 \mathrm{~m} \cdot \mathrm{y} \cdot \mathrm{km}^{3}$

\begin{tabular}{lccc}
\hline Clear Lake region, CA & 3610 & $100^{1}$ & 75 \\
Long Valley Caldera, CA & 5780 & 78 & 200 \\
Roosevelt Hot Spgs., UT & 710 & 32 & 10 \\
Salton Frough, $\mathrm{CA}^{2}$ & 480 & $230^{2}$ & 2 \\
Valles Caldera, $\mathrm{NM}^{3}$ & 8425 & 87 & 500 \\
& & & \\
lestimate for The Geysers only, does not include Calistoga, Sulphur Rank \\
Mine, Wilbur Springs, and Smal systems near Clear Lake,
\end{tabular}

2 noes not include Cerro Prieto, Mexico.

${ }^{3}$ No data available for entire Rio Grande Rift. 
regime of rifts is believed to result both from conduction through thinned crust and convective transport of heat by basaltic intrusions. Deeper drilling in rifts would improve our understanding of their thermal regime, would test geophysical interpretations of basin structures, and would provide samples representing the early history of the basins.

Deep drilling in calderas, of which the valles and Long Valley are classic examples, would directly test existing models for these systems, because the magma bodies responsible for caldera formation are thought to evolve within a few kilometers of the surface. Geologic evidence for large, shallow magma bodies beneath calderas includes:

1. Eruption of voluminous, compositionally zoned tuff sheets with contemporaneous, volumetrically-comparable collapse in the source region.

2. Post-collapse structural resurgence of the caldera floor.

3. Analogy to frozen, exhumed plutonic systems consisting of granite ring dikes enclosing downfaulted volcanic sequences and a central granite pluton. These features match in size and spatial arrangement the ring fractures, caldera fill, and resurgent dome of calderas, respectively.

Although the geology of these systems appears well understood, geophysical interpretation of their deeper portions is hampered by low density caldera fill sequences, structural complexity, and lack of confirmation by direct measurements. opportunities exist to investigate different stages of caldera evolution. The Long Valley system, with minor young 
post-collapse volcanism and low temperatures in deep wells, appears to represent a mature stage of caldera evolution with low probability of existence of shallow magma but access to the crystallized plutonic system. Higher well temperatures and more voluminous young post-collapse volcanism at the valles Caldera indicate a more prolonged or, perhaps earlier stage of evolution. The Mono Craters system (adjacent to Long Valley) of young crystal-poor, voluminous rhyolite tephra and domes extruded from an arcuate fracture system may represent an early, precollapse stage of caldera evolution. These three sites provide an opportunity to investigate not only the history of high level intrusions, but also the timing of development of hydrothermal systems with respect to these intrusions. Geologic Questions Relative to Deep Drilling

Geology is interpreted primarily from surface observations. Since local relief on the Earth's surface rarely exceeds 2 to $3 \mathrm{~km}$, geologic insights into the vertical dimension are severely limited. Conceptual models of greater vertical extent are developed by linking results of comparable fossil systems exposed at different levels. The great advantage that deep drilling offers for development of geologic models of magma-hydrothermal systems is the vertical sampling of several kilometers of a system, encompassing its volcanic, hydrothermal, and magmatic components, at a single point in time. There could be a clear answer to the question of what is presently under a volcano or geothermal field. 
This would represent a large advance for understanding of, as an example, caldera systems, where volcanoes are matched to intrusions on the basis of geometry and whole rock compositions.

Another unique opportunity provided by deep drilling is the study of magmatic crystallization. Volcanoes provide quenched samples of magmas which are less than 508 crystallized, while exhumed magma bodies have undergone a complete crystallization and subsolidus history. Thus, samples representing more than half of the crystallization history of magmas are inaccessible except by drilling.

Crystal-rich magma can be expected to occur at the outer margins of crystallizing bodies. The margin should be a key region in which to look for evidence of assimilation and differentiation processes, because thermal and chemical gradients are high. No evidence exists that material from this zone occurs in volcanic products, and the information contained in plutonic rocks concerning this zone is very limited.

Similar constraints apply to investigation of hydrothermal systems. Samples of leaking hydrothermal fluids can be obtained at the surface and samples of reservoir rocks can be obtained from cooled fossil systems. Only drilling can provide actual temperatures and access to samples of both hydrothermal fluids and their host reservoir materials.

In summary, the following geologic questions can be addressed by deep drilling: 
What is the structure and vertical thermal and chemical zonation (fluid and alteration product composition) of hydrothermal systems?

What is the structure and vertical thermal and chemical zonation of magmatic systems?

What is the relationship, in space and time between hydrothermal and magmatic systems?

What processes occur in crystal-rich magmas and what are the characteristics of the magma/wallrock or mobile magma/ crystallized magma boundary zone?

\section{GEOCHEMISTRY}

Major geochemical processes at the proposed sites occur in: 1) magmas and associated lavas, 2) hydrothermal solution, and 3) hydrothermal alteration.

\section{Geochemi stry of Magma and Associated Lavas}

Primary magma sources in the Earth's mantle are beyond the reach of present drilling technology, however, magmas that have been generated (or introduced) in the Earth's crust at shallow depth represent possible arill hole targets. The five proposed drilling sites represent such targets. However, their tectonic setting and type of magmatism appear to vary significantly.

Whereas geologic and geophysical techniques can provide information regarding the depth, size, and heat distribution of such magma bodies, igneous geochemistry is the principal method avallable in addressing questions concerning the origin and evolution of magmatic systems at a given site. Questions involving the origin, coalescence, migration, contamination, emplacement 
and crystallization of magma systems are of importance in understanding thermal regimes. Scientific dril1ing can play an important role in resolving questions of contamination during magma emplacement. It is important to note that plutonic rocks now observed at the Earth's surface, or found in drilling, have typically undergone a long and complex subsolidus cooling history resulting in mineralogical, chemical, and textural modifications which significantly limit the use of observed characteristics in the analysis of magmatic phenomena. Scientific drilling can provide samples of magmatic, or recently solidified high temperature materials which have not undergone this long and complex cooling history.

Although drilling into an active magma chamber is a longterm objective of this part of the continental scientific Drilling Program, it is reasonably clear that significant advances in the technology of drilling, logging, sampling, and instrumentation will be necessary to obtain the required scientific data. However, much information of value can be obtained prior to this stage through detailed analysis of associated volcanic rocks both at the surface and in arill cores. Geochemistry of Hydrothermal solutions

A11 of the proposed sites possess surface manifestations of hydrothermal activity to varying degrees. Two of the sites, The Geysers and to a much lesser extent, the Valles Caldera in the Rio Grande Rift, possess vapor-dominated systems. 
In general, the data describing the chemistry of both the aqueous and gaseous phases derived from deep drilling have two applications. One application is related to answering scientific questions in related fields. For example; chemical geothermometers can be used to estimate reservoir temperatures. Isotope data can be employed in estimating the age and origin of the hyarothermal water. Trace element data can be used to define avenues of recharge into the hydrothermal reservoir. Dissolution and aqueous equilibrium constraints can be applied to determine the effects of aqueous chemistry in controlling secondary permeability and reservoir evolution.

A second approach is to use the data to answer basic questions concerning chemical mechanisms and evolution of hydrothermal fluids. For example, the literature indicates that the hydrothermal chemistries at all sites are high in certain trace elements such as As, $B, B r, F$, and $L i$. What are the sources of these elements? To what extent are they derived directly from juvenile or magmatic sources and to what extent from dissolution of reservoir rocks? What is the source of the abundant sulfur associated with these hydrothermal solutions and gases? The fluid chemistry at all five sites is generally dominated by sodium chloride either as dilute or concentrated brines. Can such similarity in chemistry result from very different mechanisms? For example, evaporite dissolution has been suggested in the Salton Trough as compared to rhyolite dissolution in Long Valley. Does such similarity indicate a common trend in evolution? Are 
vapor-dominated systems such as The Geysers underlain by concentrated sodium chloride brines?

Another major geochemical question to be addressed is the relationship between hydrothermal solution and formation, transport, and deposition of ore-forming elements. Is mercury deposition indicative of a present or past vapor-dominated system? What is the source of heavy metals in the Salton Trough and is the ir transport directly related to the concentrated brine chemistry? Are the sources of the se elements related to a magma system or do they result from leaching of reservoir rocks?

To adequately interpret geochemical data on solid, liquid, and gas samples of the Farth's crust obtained in a CSnP, there is a requirement for broad-based generic research on fundamental geochemical processes. This includes such basic rock/water interactions as the kinetics of dissolution and precipitation at high temperatures as well as speciation of chemical elements in aqueous phases in concentrated solutions. In addition, technological advances in sampling in-situ solutions at high temperatures, pressures and great depths must be developed. Geochemistry of Hydrothermal Alteration

In a sense, hydrothermal alteration represents the interface between the aqueous and/or vapor geochemistry and the geochemistry of the reservoir rock. Hydrothermal alteration is dependent on the distribution of thermal energy, controlled, for example, by hydrologic constraints such as the development of hydrothermal 
circulation. The chemical changes are also restricted to portions of the system where fluid/rock interactions can occur by advection of components, intergranular diffusion, and both equilibrium and nonequilibrium reactions. Rydrothermal alteration may, in turn, increase or decrease rock permeability and affect both circulation and convective heat transport. Alteration assemblages offer a record of present hydrothermal processes and also of past spatial, chemical, and temperature regimes in such systems. This record is important in assessing whether hydrothermal alteration reduces permeability sufficiently to cause a liquid-dominated hydrothermal system to evolve into a vapor-dominated system. The spatial distribution of hydrothermal alteration is also important in evaluating geophysical anomalies associated with geothermal sites.

Deep drilling also offers an opportunity to observe alteration assemblages and specific hydrothermal solutions at known temperatures and pressures. These data will provide much needed tests of existing mass transfer codes. In addition, it will be possible to evaluate the lower temperature limits for fluid/rock chemical equilibrium and the effect of reservoir rock type and temperature on the observed alteration sequence.

\section{GEOPHYSICS}

The needs for geophysical research at each site are summarized below, first for potential magma targets, then for hydrothermal targets. 
Geophysical Evidence for Magma at Depth

Because the tectonic settings and modes of occurrence of intrusive rocks are different at the five sites, the means by which the existence of magma from geophysical data can be inferred differ from site to site. The sites can be placed in two groups: those for which the occurrence of distributed bodies of magma is inferred from a regional tectonic model and those where geo$\log 1 \mathrm{c}$ and geophysical evidence indicates the presence of a localized magma body. The Rio Grande Rift and the Salton Trough are in the first group; Long Valley, Roosevelt Hot Springs, The Geysers-clear Iake area, and the Valles caldera fall in the second group.

The sites related to localized magma bodies share many common characteristics. The most direct evidence for magma relates to seismic attenuation and delays, anomalously high electrical conductivity, gravity lows, high local heat flows, and reduced seismicity associated with molten rock. At some sites le.g., Roosevelt Hot Springs), the geophysical evidence for the inferred magma body is sparse; at others (e.g., The Geysers-clear Lake), several geophysical methods indicate that the body exists. Magma Targets in the Rio Grande Rift

The regional model of tensional deformation for the Rio Grande Rift is generally accepted even though recent seismicity and deformation measurements fall to confirm 1 t. seismic refraction and reflection studies indicate complex graben-horst structures in 
a sedimentary basin overlying a thin $(34 \mathrm{~km})$ crust and a mantle with low P-wave velocity. Regional magnetic and gravity lows and inferred high conductivities for the crust or upper mantle support this picture. Local zones of high and variable heat flow are superimposed on regionally high heat flow. Passive and active seismic reflection methods have detected a particular target area near socorro. This extensive $\left(1700 \mathrm{~km}^{2}\right)$ target is interpreted as being formed of thin, sill-1ike intrusions at a depth of $20 \mathrm{~km}$ and smaller intrusions at shallower depths. Little is known about these bodies apart from their locations as determined by seismic reflection. Near-surface heat flow is high above the 20-km-deep body near Socorro, but the temperature of the body and the thermal structure between the body and the surface have not been studied. Vertical deformations observed above this target can be interpreted as resulting from inflation or deflation of magma chambers at $20 \mathrm{~km}$ depth, but more studies are needed.

The Valles Caldera presents a different type of target. Extensive volcanism (as recently as $0.1 \mathrm{my}$ ago) high temperatures in the geothermal field, and the absence of seismicity suggest that a massive intrusion may be cooling beneath the Caldera. Current geophysical evidence, heat flow, gravity, and magnetotellurics, does not define a target. Teleseismic delay and attenuation studies, seismic surveys, and geoelectric measurements all could contribute to target definitions, if unique 
Interpretations can be made with in the circular geometry of the Caldera.

Magma Targets at the Salton Trough

The Salton Trough has a combination of tensional and shear tectonic activity. Long, en echelon strike-slip faults are connected by short active spreading centers in a region of thinning crust and rapid sedimentation. several possible spreading centers in the Trough have been identified and are good candidates for studies of continental-crust augmentation by distributed intrusions.

Several types of geophysical data are used to characterize the regional model. Gravity and seismic refraction data define the structure; up to $6 \mathrm{~km}$ of sediments lying in a trough over a thin (about $20 \mathrm{~km}$ ) crust with velocities appropriate to oceanic crust at depths of 10 to $16 \mathrm{~km}$. High rates of regional subsidence indicate that crustal thinning is presently active.

Local gravity maxima indicate cementation of sediments at a depth of less than $4 \mathrm{~km}$ at East Mesa, a dense basement feature 6 to $7 \mathrm{~km}$ deep at Brawley, and intrusions and/or metamorphism shallower than six kilometers at the salton sea Geothermal field. A positive magnetic anomaly at the latter site is interpreted to show that cooled intrusions occupy $10-208$ of the volume of rock as shallow as 1 kilometer depth, and that a substantial dike complex exists below 2.5 kilometers. Local heat flow is high at all the spreading centers and wells at several sites have encountered thin intrusive bodies. 
Additional geophysical work in the Salton Trough could be directed toward identifying specific target bodies at each spreading center and determining whether they are still molten. Seismic reflection and teleseismic delay studies might provide more information in areas where the salton sea does not interfere with instrument siting. Magma Target at Long Valley

Long Valley may provide a locale for drilling toward a silicic magma chamber associated with recent, extensive volcanism. Selsmic refraction, teleseismic P-wave delays, and gravity data all support the interpretation that a zone of magma or partial melt as large as $10 \mathrm{~km}$ diameter could 1 ie only $7 \mathrm{~km}$ below the surface. However, heat flow and thermal gradient data suggest a deeper level for the heat source.

Reflections recorded on a seismic refraction profile indicate a low velocity region $5-8 \mathrm{~km}$ across at $7 \mathrm{~km}$ depth. A gravity low is interpreted as indicating a low density body of uncertain size at $8-16 \mathrm{~km}$ depth. One interpretation of teleseismic data indicates a low velocity body at 7-12 km depth and 8-10 km in diameter. Confidence, in these interpretations will be strongly influenced by evaluation of data recently released from two drill holes that did not show the steep conductive gradients expected above such a body.

The major need at Long Valley is to resolve the apparent contradictions between interpretations based on geophysics 
(seismic and gravity) and on thermal gradient data from existing holes. An understanding of the specific paths of fluid flow and the geometry of convective heat transport is essential to reconcile those interpretations.

Magma Target at Roosevelt Hot springs

There is no direct geophysical evidence of a magma body at Roosevelt Hot Springs. An attractive target may lie beneath the Mineral Moutains, but additional work is required before the depth, size, or nature of that proposed target can be discussed. Simple heat flow models suggest a potential magma source could be deeper than $7 \mathrm{~km}$. Other geophysical data do not show effects of a magma body. Gravity and magnetic observations are adequately explained by known, near surface features. Geoelectrical neasurements have been strongly influenced by near surface conductivity variations. Preliminary $P$ and $S$ wave travel studies indicate a possible site for a body but are not conclusive. A simple model of deep convection along normal faults in a Basin and Range tectonic environ- ment is consistent with the hydrothermal systems. Magma Target at The Geysers-Clear Lake Area

Several geophysical methods point to an area of approximately $200 \mathrm{~km}^{2}$ of highly attenuative, low-strength material of low density and velocity that could be as shallow as 7 to $10 \mathrm{~km}$. These data include a gravity low without a corresponding magnetic anomaly, interpreted as indicating a low density (partially molten) body in the crust at 8 to $14 \mathrm{~km}$ depth. $P$ wave delays and attenuation 
studies indicating a low velocity zone in the upper $30 \mathrm{~km}$ and seismic refraction studies show that the low velocities must be deeper than $4 \mathrm{~km}$. The actual depth and temperature of this target have not been confirmed by heat-flow estimates from drill holes passing beneath the hydrothermal system. Evidence for Hydrothermal Systems

Rydrothermal systems are usually discovered because of such surface manifestations as hot springs, seeps, or altered surface rock. Geophysical measurements are used to define the extent and resource potential of the se systems. Hydrothermal Systems at the Rio Grande Rift

Rey evidence for the existence of hydrothermal systems in the Rio Grande Rift zone comes from surface geological features, spring occurrences, and petrographic-geochemical data. The large variability of heat-flow values within the $R$ ift zone implies a dynamic geothermal environment at shallow depths: hydrothermal systems contribute to this variability throughout the Rift. The valles hydrothermal system in the Rift has been extensively drilled and found to have temperatures as high as $300^{\circ} \mathrm{C}$. It is an attractive target to study because it is both well-defined and hot. Industrial interest could provide extensive data. Hydrothermal Systems in the Salton Trough

Hydrothermal systems in the Salton Trough are generally large, relatively high-temperature systems, and their characteristics have been well documented. These hydrothermal systems have many 
features in common. Fach system is found in a relatively simple geological environment. They are all liquid-dominated systems which occur in young sedimentary rocks with high porosity and permeability, capped by rocks of low permeability several hundred meters thick.

The largest system (excluding Cerro Prieto, Mexico), the Salton sea Geothermal Field, has been well characterized by wells on the order of $2 \mathrm{~km}$ depth which show temperatures up to $360^{\circ} \mathrm{C}$. Heat flow, resistivity, magnetic data, and seismicity show the lateral extent of the system beyond the drilled area, indicating the total area is at least $50-120 \mathrm{~km}^{2}$. The system may also extend beneath the salton Sea where additional heat flow data are needed to confirm its total extent. The total thickness and lower boundary of the system have not been determined.

Hydrothermal Systems at Long Valley

Geophysical data cover an area of about 50 to $200 \mathrm{~km}^{2}$ in Long Valley where hydrothermal convection is important in the upper $600-1000 \mathrm{~m}$. Measured temperatures in that system are up to $160^{\circ} \mathrm{C}$, but geochemical estimates of reservoir temperature are higher. The hydrothermal system has not been characterized adequately to determine the thickness of the convecting systems, airections of fluid flow, or the amount of fluid involved. Well logs and geophysical evidence indicate substantial volumes of porous Bishop tuff within the Caldera, suggesting that the hydrothermal system could be large and extensive. Low temperatures 
and low gradients at depth in deep wells indicate that the location of the high-temperature part of the system is not known and courd be quite deep.

An area of $40 \mathrm{~km}^{2}$ shows high and variable heat flow indicating shallow convection. Deep holes indicate that lateral flow is important and that the hydrothermal system is at least $600 \mathrm{~m}$ thick.

Hydrothermal System at Roosevelt Hot Springs

High heat flow is found in an area of more than $40 \mathrm{~km}^{2}$. Faults and fractures control the fluid flow. They are mapped by aeromagnetic surveys which sense the truncation of volcanic beds, and by resistivity surveys which sense clay in fault zones. Reported well temperatures are as high as $269^{\circ} \mathrm{C}$.

The details of the deep plumbing of the Roosevelt system are not well known. The hydrothermal system here apparently has few inherently unique physical properties, only high temperatures and high electrical conductivity in relatively localized fault zones. Hydrothermal System at The Geysers-Clear Lake Area

The vapor-dominated hydrothermal system at The Geysers is large, covering 50 to $100 \mathrm{~km}^{2}$ to a depth of at least $3.5 \mathrm{~km}$, and hot (approximately $240^{\circ} \mathrm{C}$ ). Projected commercial production of over 1.0 GWe testifies to the certainty of that system's existence. Unknown features of the system include: its total depth, what lies beneath it, and its evolution. 
Most information about the hydrothermal system has come from drilling. Because of the complex geologic setting, the physical properties of the hydrothermal system could not be predicted without measurements from drill holes. consequently, geophysical data have only served to supplement the drill hole data. Gravity and magnetic anomalies map out the steam field. Seismic reflection data indicate structures within the Franciscan rocks which may be shear zones controlling the fluid paths.

Comparatively iittle is known about the extent of the hydrothermal system associated with the clear I,ake volcanic field. Two holes have apparently encountered temperatures of $180-200^{\circ} \mathrm{C}$ in the midale of an extensive resistivity low. If the resistivity low represents the size of the hot water system, then its area could be as great as $60 \mathrm{~km}^{2}$.

\section{PROPOSED RESEARCH AND DRILLING PLANS}

In attempting to Identify site-specific scientific questions requiring resolution by drilling, it is necessary to appreciate that a single drill hole provides only a one-dimensional sample and a Iine source for experiments at one point in (geologic) time. Sclentific questions involving evolution of magma and hydrothermal systems must be considered carefully in the $1 \mathrm{ight}$ of the se spacetime constraints.

Even with the most careful, thorough, thoughtfui, and intensive site selection and pre-drilling activities it is highly 
probable that many of the observations made through drilling will be unforeseen. Consequently, the arilling plan must be flexible, and directed by an on-site scientific team. The drilling program must plan to resolve scientific questions that will evolve during drilling, and not simply aim to "make hole".

Factors which should be considered in the development of sitespecific research and drilling plans include:

The scientific questions to be addressed.

Is drilling necessary for the resolution of the scientific questions?

What level of drilling, logging, sampling, and instrumentation technology is adequate for resolution of the scientific questions?

Are present geological, geochemical, geophysical data adequate to define a meaningful drilling program?

What is the nature, magnitude, and extent of generic supportive research which is required?

Can drilling for technological purposes be used for "add-on" experiments which will provide data useful in the resolution of the scientific questions?

Do quantitative models bearing on heat and mass transport within and between magma systems exist at the specific site and can they be tested by scientific drilling?

To what extent will resolution of these scientific questions shed light on the origin and development of fossil analogue systems?

An important point is that the principal role of the CSDP is to provide enhanced understanding of crustal phenomena and to stimulate scientific and technological advances. 
This section summarizes the information on the specific sites, identifies site-specific scientiflc questions, and suggests drilling plans.

\section{Salton Trough}

Six hydrothermal systems in the Salton Trough have been drilled, but direct evidence for magma is not definitive. Indirect evidence derived from the regional tectonic model indicates the presence of intrusions, perhaps as dike swarms, at depths of $2-10 \mathrm{~km}$. Scientific drilling in this area would provide valuable information on the roots of an economically important geothermal system and their relationship to hot dikes, but perhaps only Iimited information on their magmatic source. It is probable that magma targets are small and distributed.

The intensive geothermal development of the area has led to comprehensive qualitative models of the region based on seismic refraction, gravity, electrical, magnetic, heat flow, geodetic, and geologic data. At Cerro Prieto, Mexico, detailed studies leading to extensive conceptual and quantitative models, specifically for reservoir engineering, have been completed or are in progress. In the salton sea region, local qualitative models exist. Continental scientific Drilling in this area could result in development of quantitative models applicable to a number of "fossil" analogues such as the Tertiary Brito-Arctic volcanic province and currently active analogs such as the Red Sea-Afar system. In addition, observations obtained through a CSDP can 
be used to test, validate, and develop models based on extensive geophysical data.

There is an extensive drilling program for geothermal exploration and production in the Salton Trough. At Cerro Prieto there are in excess of 60 wells $(1.4-3.5 \mathrm{~km}$ deep) with temperatures up to $350^{\circ} \mathrm{C}$. All data are in the public domain and there is a production history of ten years. In the Salton Sea region there are more than 20 wells $(1.5-2.8 \mathrm{~km})$ with temperatures in excess of $300^{\circ} \mathrm{C}$. Much of the data from the se wells is proprietary. Exploration and production drilling for the geothermal re source in this field may continue, perhaps providing opportunities for add-on scientific experiments.

A scientific drilling program in the Salton Trough could address a variety of specific questions related to hydrothermalmagma systems:

What underlies the $350^{\circ} \mathrm{C}$ hydrothermal region (temperature, fluid composition, metamorphic mineral assemblage, density, porosity, permeability); and does the subhydrothermal region affect the near surface geothermal system and relate to thermal sources at depth?

To what extent is deep-seated ( $>3 \mathrm{~km}$ ) hydrothermal circulation important in recharge and chemical alteration of the near-surface geothermal system?

Do systems near the critical point of the hydrothermal fluid have distinctive physical and chemical properties that are important in terms of mineralogic reactions and the generation of fluids akin to ore forming fluids?

Is the Salton Trough underlain by continental or oceanic (or both) crust? 
Are basaltic dike swarms emplaced along "leaky transforms" the heat source driving the geothermal system(s)?

What is the relationship of surface volcanic phenomena, (rhyolitic), to the postulated subsurface (basaltic), source?

At present, one of the problems associated with scientific drilling in the salton Trough is the lack of a distinct magmatic target. Specific drilling directed toward resolution of problems associated with magmatic and transition zone (magma-hydrothermal) problems requires additional geophysical studies for location of possible magma bodies. Both seismic reflection and teleseismic delay studies would be appropriate. Several of the questions require information from depths immediately below those reached in current drilling. Obtaining this information will require a technological capability for sampling rock, fluid, and gas at temperatures in excess of $350^{\circ} \mathrm{C}$ and pressures up to 1 Kbar.

After the development of adequate drilling, logging, sampling. and instrumentation technology to resolve the scientific questions, a scientific arilling program to drill a $5 \mathrm{~km}$ deep hole at the Salton sea is recommended. This drilling would focus on resolution of the first three questions above and provide some basis for selecting a $10 \mathrm{~km}$ deep hole site.

supportive research related to a scientific ariling program in the Salton Trough would include a geophysical study directed toward locating and evaluating specific magma bodies, and detailed mineralogic, petrologic, and geochemical studies concerned with 
the relationship of the exposed rhyolitic volcanics to the igneous rocks found in the subsurface. It is probable that a number of the existing wells at depths in excess of $2 \mathrm{~km}$ could be used for development and testing of a variety of both active and passive downhole geophysical methods. Rio Grande Rift

The reports of the Geology, Geophysics, Energy Transport, and Geochemistry working groups focus principally on two targets in the Rio Grande Rift( the Valles Caldera and the Socorro anomaly) although attributes of the rift in its entirety are covered.

\section{Valles Caldera}

The Valles Caldera in the Jemez Volcanic field lies at the junction of the northeast trending Jemez lineament, or zone, and the Rio Grande Rift. Volcanic activity has been active from $10 \mathrm{my}$ BP to less than $0.1 \mathrm{my}$ BP. The two voluminous ( $100 \mathrm{~km}^{3}$ ) rhyolitic eruptions responsible for the Bandelier muff were at 1.4 and $1.1 \mathrm{my}$ BP. Deep drilling $(2-3 \mathrm{~km})$ in the resurgent dome of the caldera has identified temperatures of $300^{\circ} \mathrm{C}$. Hot springs along major rift-bounding faults southwest of the caldera appear to be mixtures of near surface meteoric and deep thermal waters. Thermal waters discharging at the surface in the caldera have low $\mathrm{pH}$ and high sulfate content, but the high temperature fluid at depth is chloride rich. 
The evidence for a hydrothermal system in the caldera is reasonably clear and is supported by a $40 \mathrm{~km}^{2}$ region of hydrothermal alteration, generally coinciding with the resurgent dome in the caldera. The evidence for magma, as contrasted with igneous rock, is far less direct. There is high heat flow (> 4.5 HFU) within the Jemez field. The Jemez volcanic field is ringed by moderate earthquake activity in the upper $20 \mathrm{~km}$ of the crust but is notably aseismic in a $50 \times 100 \mathrm{~km}$ elliptical area centered on the Valles Caldera. Calculations, based on thermal models and influx of magma to form the resurgent dome, suggest that a cooling silicic magma chamber could still retain a temperature of $600^{\circ} \mathrm{C}$ at $7 \mathrm{~km}$ beneath the Caldera complex. There are no direct indications of magma by passive or active seismic methods, such as the case at socorro.

Although the Jemez Volcanic Field has been the subject of Intensive and thorough geologic mapping on a regional scale, a comprehensive quantitative model amenable to testing by a scientific drilling program is not currently available.

A scientific drilling program emphasizing features associated with the resurgent dome of the valles caldera would provide information of value in developing an understanding of general relations in caldera-forming geologic systems. Fossil analogues include plutonic complexes such as the Mesozoic analogues in New England and the Tertiary examples of scotland. More recent examples would include yellowstone, Long valley, the multiple tertiary silicic 
centers of Southern Nevada, and the San Juan Mountains of Colorado. Because of the catastrophic and widespread nature of silicic volcanism associated with caldera formation, an understanding of processes leading to the development of such features is of fundamental importance.

There is a considerable effort directed toward development of the geothermal resource in the Jemez region, specifically within the Valles Caldera. There may be opportunities for scientific experiments of an add-on nature. Most of the planned drilling will be in the range of less than $3 \mathrm{~km}$ with a target temperature near $300^{\circ} \mathrm{C}$.

A scientific drilling program in the Valles Caldera could address several specific questions related to hydrothermal-magma systems :

What is the nature of the hydrothermal system at depths corresponding to temperatures in excess of $300^{\circ} \mathrm{C}$ ?

What is the nature of the geothermal plumbing system, including recharge and flux from depth, at depths in excess of three kilometers?

Is the thermal source solidified or active magma, and how does it relate (chemically, mineralogically, and physically) to the space-time evolution found in this volcanic field?

What is the nature of the transition region between the hydrothermal and magma (or still hot igneous rock) zones?

How do the attributes of the transition and magma zones, as sampled at high $\left(>300^{\circ} \mathrm{C}\right)$ temperatures, relate to fossil analogues which have undergone a long and slow cooling history? 
There is a persuasive body of evidence indicating magma or still hot igneous rock underlying the Caldera at depths less than $10 \mathrm{~km}$. Additional geophysical studies would be required to develop a detailed drilling plan. of critical concern, as in the case of the salton Trough, is the need for adequate drilling, logging, sampling, and instrumentation technology to permit resolution of the scientific questions.

The proposed drilling program for the valles consists of a deep hole $(\sim 10 \mathrm{~km})$ sited on the resurgent dome. Technological developments would be required and a moderate depth $(\sim 5 \mathrm{~km})$ hole would be the initial target. Supportive research needs would be largely in the areas of detailed geophysical studies, and of resolving stratigraphic and structural problems in the older volcanic sequences of the area.

\section{Socorro Anomaly}

The socorro anomaly in the southern segment of the Rio Grande Rift lacks significant and related surface volcanic or hydrothermal manifestations, but several lines of geophysical evidence point to the existence of sili-1ike bodies of magma. Recent cocorp data indicate the possibility of a small magma body at depths less than $5 \mathrm{~km}$, in addition to the $19-20 \mathrm{~km}$ sill-like bodies. We cannot currently consider drilling to $20 \mathrm{~km}$; however, the shallow body is potentially accessible. Because of a (current) lack of geothermal interest at this site there is little potential opportunity for add-on scientific experiments. 
The scientific questions appropriate to this site center about the nature of the anomaly:

1. What is the mechanism of magma emplacement?

2. In view of the lack of surface manifestations, does this site represent a pre-volcanic situation?

3. What is the nature of the rifting process?

A scientific drilling program at this site requires additional geophysical studies in addition to the development of a technological base. In addition to resolving scientific questions of the type just noted, a scientific drilling program at this site would be valuable in terms of understanding rift structure, sedimentation, and evolution as well as providing a calibration of geophysical tools applicable to the rift in general.

\section{Long Valley}

The Long Valley Caldera is an elliptical depression, $17 \mathrm{~km}$ by $32 \mathrm{~km}$. Volcanic activity in this area on the eastern side of the Sierra Nevada has persisted to the last 500 years. Hydrothermal activity is localized along the caldera moat and in the resurgent dome and is interpreted as being controlled by caldera ring fractures and the keystone graben. There are a large number of shallow $(<30 \mathrm{~m})$, several moderate $(<300 \mathrm{~m})$ and three deep ( $2 \mathrm{~km}$ ) drill holes in the Caldera. The deepest holes are characterized by temperature reversals with gradients of about $37^{\circ} \mathrm{C} / \mathrm{km}$ at depth. Substantial lateral flow and convective transport are indicated. 
Direct evidence for a magma system is based on active and passive seismic results and gravity survey. Seismic refraction data suggest a possible interface at $7 \mathrm{~km}$ with an underlying zone of lower velocity. Teleseismic data are consistent (non-uniquely) with a zone of reduced velocity at depths greater than $7 \mathrm{~km}$, extending perhaps to $19 \mathrm{~km}$, suggesting high temperature effects such as partially molten material. Gravity data are consistent with a deep $(8-16 \mathrm{~km})$ lower density source.

The recent arilling indicating low geothermal gradients $\left(37^{\circ} \mathrm{C} / \mathrm{km}\right)$ measured at depths of approximately $2 \mathrm{~km}$ would suggest $600^{\circ} \mathrm{C}$ at $15 \mathrm{~km}$. This temperature would preclude the existence of magma at depths accessible by drilling. The very recent. (< 500 years) volcanic activity along the Inyo fracture zone on the west side of the caldera suggests recent magma. The main question is: does magma still exist, and at what depth. In view of the low temperatures observed at depth in the recent. drilling it can be anticipated that interest of the geothermal industry will wane and that few opportunitles for add-on scientific experiments will present themselves.

Many of the scientific questions of interest to the CSDP at Long Valley center about validation of general concepts of caldera development in terms of structure and eruptive history. However, Long Valley caldera offers no more promise than other. examples, such as the valles Caldera, for studies bearing on such questions. Long valley may provide an opportunity for study 
of a recently crystallized epizonal pluton at modest temperatures. one of the recent $2 \mathrm{~km}$ holes has apparently penetrated $400 \mathrm{~m}$ into such a body and thus samples are avallable.

We conclude that Long valley. Is not a high priority target for an early cSnp effort. The Geysers-Clear Lake Area

The two topics are covered together because the major geothermal systems are at The Geysers steam field and the potential magma target underlies the clear Lake area some $10 \mathrm{~km}$ to the northeast.

There are two geothermal systems in The Geysers-Clear Lake region, the large and well-known vapor-dominated system and a less well defined hot-water hydrothermal system to the east and north. The collayomi fault zone, trending NW-SE, is active and separates the two provinces.

Reservoir rocks for both geothermal systems are within marine rocks of the Franciscan assemblage and to a lesser extent the Great valley sequence. Production is controlled by faults, fractures, and structural traps. Intrinsic permeability is low, in part due to hydrothermal recrystallization of the melange. The heat source inferred for the geothermal system is presumed to be silicle magma associated with the clear Lake volcanic field.

There are two principal types of geothermal fluids in the area: (1) the steam condensate and derivative waters associated with The Geysers field, and (2) a more complex and variable suite 
of fluids, rich in chloride and bicarbonate, assoclated with hot water systems to the east and north of the collayomi fault zone. The model for development of a vapor dominated system involves steam evolution from a boiling brine. Drilling to depths of greater than $3.7 \mathrm{~km}$ in The Geysers field has not found the "parental" brine. Dikes and sills of porphyritic volcanics found in drill holes at The Geysers represent an early ( 1 my) phase of silicic volcanism which cannot be the direct source of heat for the vapor-dominated system. The temperature at the Geysers field is about $240^{\circ} \mathrm{C}$ at depths of nearly $4 \mathrm{~km}$. Exploration wells drilled in the clear Lake volcanic field indicate temperatures of $200^{\circ} \mathrm{C}$ at depths of $2 \mathrm{~km}$.

Although the case is quite clear for the extstence of hydrothermal systems at The Geysers-Clear Lake area, the case for active magma is less well defined and rests principally on geophysical data. A nearly circular gravity low, beneath the Clear Lake Volcanics, centered on Mt. Hannah, has been ldentified, The negative anomaly is assumed to reflect a low density sillcic differentiate at a depth of $6-14 \mathrm{~km}$. The requisite density contrast can be satisfied if a partially molten silicic body, i.e., a magma, is postulated. There is no magnetic anomaly related to the gravity low. However, interpretation of magnetic data in a basement environment as structurally complex as the Franciscan assemblage is quite difficult. Teleseismic P-wave delay and regional selsmic attenuation are consistent with the 
existence of a magma body at depths in excess of $4 \mathrm{~km}$ underlying Mt. Hannah. Earthquake hypocenters are not observed at depths in excess of $5 \mathrm{~km}$ in the Mt. Hannah area, al so consistent with a high temperature, possibly magmatic, regime at depth. Resistivity and heat flow studies provide somewhat limited support for the existence of a magma body underlying Mt. Hannah.

Detalled quantitative models, amenable to testing through a scientific arilling program, are not available for the GeysersClear Lake area. Given the structural complexity and heterogeneity of the Franciscan assemblage it is not clear that such models should be constructed.

It can be anticipated that continued geothermal production activity in The Geysers field will provide abundant opportunities for scientific experiments of an "add-on" nature. Direct opportunities will presumably be 1 imited to the temperature range less than $250^{\circ} \mathrm{C}$ at depths to $4 \mathrm{~km}$. There may also be 1 imited opportunities for similar "add-on" experiments associated with commercial exploratory drilling in the hot-water geothermal reservoirs to the north and east of The Geysers.

A number of important scientiflc questions bearing on the origin and development of magma and hydrothermal systems could be addressed through a scientific drilling program in this area.

Does a bolling brine underlie the vapor-dominated geothermal system?

What is the nature of the transition zone between the hot-water geothermal system and the underlying magmatic system? 
To what extent are the vapor-dominated and hot water geothermal systems coupled?

Why is the youngest volcanism displaced to the northeast of the geophysically defined magma body and The Geysers steam field to the southwest of the postulated body?

A carefully conceived, comprehensive, and extensive program of scientific drilling will be required, given the structural and geologic complexity of the area. As in the case of the salton Trough and the Rio Grande Rift, resolution of the scientific questions requires the capability to obtain solid, liquid, and gas samples at high temperature and depths in excess of $4 \mathrm{~km}$. Drilling, logging, sampling, and instrumentation technology will need to be advanced as part of CSDP in order to address these questions.

Scientific drilling at The Geysers provides a unique opportunity to assess the roots of a vapor-dominated geothermal system. This uniqueness does limit potential application of the results to other active and fossil geothermal systems.

The outline of a drilling plan has been developed, assuming adequate technology, for The Geysers-Clear Lake Region. The plan involves two deep $(5-8 \mathrm{~km})$ holes. The first would be at The Geysers and the second would be on the Mt. Hannah anomaly.

Supportive research might well include detalled and local seismic reflection and refraction studies. In addition existing wells in the area could be used to develop and test a variety of hole-hole active and passive geophysical methods. 
Roosevelt Hot Springs

The Roosevelt Hot Springs, in southwestern Utah, is on the west flank of the Mineral Mountains. The Mineral Mountains Tertiary (< 35 my BP) pluton is the dominant unit of the Mineral Mountains. P-wave delay studies suggest a low-velocity zone at depths of 10-25 km and the possibility of a smaller low-velocity body at a depth of $5 \mathrm{~km}$ or less underlying the central Mineral Mountains. There are abundant hot springs deposits in the area which appear to be localized by faulting. Hydrothermal alteration is associated with fractures in the Mineral Mountains pluton. At this stage there is not a comparable data base for comparison with the other four sites. It appears that this site is not a primary candidate for the initial stages of a scientific drilling program.

\section{CONCLUSIONS}

A scientific drilling program focused on problems associated with Hydrothermal-Magma Systems provides a valuable opportunity to advance the state of earth science and contribute to the attainment of DOE objectives. Although geologic, geochemical, and geophysical studies provide information on geothermal systems, the resulting models are nonunique and require confirmation, or validation. Petrologic and geologic studies provide information on integral aspects of crustal processes and can be used to infer relations in the past. One of the most exciting facets 
of the program is the opportunity to obtain samples (solid, liquid, and gas) at deep crustal temperatures and pressures. Such samples can provide direct information on the state of the magma-hydrothermal system in terms of chemical, mineralogical, and physical properties. The importance of this opportunity cannot be overstressed when it is realized that the bulk of our geological, geochemical, and geophysical conceptual and quantitative modeling is based on examination of exhumed magmahydrothermal systems and "quenched" volcanic samples. In the case of exhumed magma-hydrothermal systems the samples that we collect at the Earth's surface have undergone a long and complex postmagmatic cooling process. Inevitably, key chemical, mineralogical, and physical attributes are changed during the cooling process, posing major problems in interpreting the high-temperature processes. On the other hand the quenching inherent in the case of volcanic samples can provide information only on preeruption and eruption processes. Samples from an active hydrothermal-magma system can provide the basis for linking the two traditional kinds of studies.

The relationship to DOE objectives stems from the vital needs of the agency to develop a fundamental and predictive understanding of the consequences of energy-related thermal perturbations on processes and materials of the Earth's crust... This program will foster and further such an understanding in a generic sense with applications in the geothermal, nuclear waste disposal, and 
in-situ coal and oil shale. A second payoff to the agency will result from the development of drilling, logging, sampling, and instrumentation technology for very hostile geologic domains. However, a scientific drilling program focused on Hydrothermal-Magma systems is subject to a number of constraints and limitations. The objective is to resolve scientific questions. This implies that an adequate technology exists, that the orilling program does not emphasize the logistics of drilling but rather evolves scientifically during the drilling, and finally that scientific questions require drilling for their resolution. It must be recognized that a drill hole provides what is essentially a one-dimensional sample, or experimental facility referenced to one point in time.

This review has considered five specific sites. Each site is somewhat different in terms of scientific opportunities and challenges. In terms of further activities leading to site selection we recommend that they center about the Valles Caldera, The Geysers-Clear Lake Region, and the Salton Trough. We do not believe that the available data warrant serious consideration of Long Valley or Roosevelt Hot Springs as early candidates. Within the three principal sites, considering the the combination of magma, hydrothermal zones and potential applications to other other areas, we believe that the Valles Caldera offers the greatest advantage as a site. 
We must al so point out that other potential sites exist for scientific drilling related to hydrothermal-magma systems, for example, Yellowstone and the Cascades. Yellowstone was not considered here because of environmental reasons, as noted in the NAS "Continental Scientific Drilling Program" report. The same report noted (p. 102) that "The diversity and number of stratovolcanoes in the United States preclude an Intelligent drilling program at this time." with respect to the cascades.

The Thermal Regimes Panel of the NAs continental scientific Driling committee has provided valuable review comments on a previous draft of this summary. We are confident that incorporation of a number of the suggestions of this panel has resulted in significant improvement. However, the responsibility for errors of fact, interpretation, and analysis necessarily rests on the authors. It is our hope that this summary, and more importantly, the four supporting documents, will be of value to the scientific community in pursuing the objectives of a continental scientific Drililing Program. 